NBER WORKING PAPER SERIES

BOLIVIA'S ECONOMIC CRISIS

Juan Antonio Morales Jeffrey Sachs

Working Paper No. 2620

NATIONAL BUREAU OF ECONOMIC RESEARCH 1050 Massachusetts Avenue

Cambridge, MA 02138

Harvard University and NBER, and Universidad Catolica Boliviana, respectively. This paper is a summary of a monograph on "Bolivian Economic Performance and Foreign Debt", undertaken as part of the NBER project on Developing Country Debt. The research supported here is part of the NBER's research program in International Studies. Any opinions expressed are those of the authors and not those of the National Bureau of Economic Research. 
NBER Working Paper \#2620

June 1988

Bolivia's Economic Crisis

ABSTRACT

\begin{abstract}
By any standard, Bolivia's economic crisis in the $1980^{\prime} s$ has been extraordinary. Like lts nelghbors, Bollvia suffered from major external shocks, but the extent of economic collapse in the face of these shocks (Including a hyperinflation during 1984-85) suggests that internal factors as well as external shocks have been critical to Bolivia's poor economic performance. One major theme of our work is that the recent economic crisis in Bolivia is a reflection of political and economic conflicts in Bolivian soclety that have undermined the development process throughout this century. While major reforms have been begun by the present government, many of the deepest problems in Bolivian soclety that contributed to the crisis remaln unresolved.
\end{abstract}

Juan Antonio Morales

Universidad Catolica Bollviana

Av. 14 de Septiembre 4807

Cajon Postal No. 4807

La Paz

BOLIVIA
Jeffrey Sachs

Department of Economics

harvard UnIversity

Littauer $\mathrm{M}-14$

Cambridge, MA 02138 


\title{
Bolivia's Economic Crisis
}

\author{
Juan Antonio Morales and Jeffrey Sachs
}

\section{Introduction}

By any standard, Bolivia's economic cris is in the 1980's has been extraordinary. As seen in Table 1, Bolivia's economic debacle of recent years is striking even in comparison with the poor performance of Bolivia's neighbors. Like its neighbors, Bolivia suffered from major external shocks, including the rise in world interest rates in the early 1980s, the cutoff in lending from the international capital markets, and the decline in world prices of Bolivia's commodity exports. But the extent of economic collapse in the face of these shocks suggests that internal factors as well as the external shocks have been critical to Bolivia's economic performance. The Bolivian hyperinfiation of 1984-85, for example, which was one of the most dramatic inflations in world history, is the oniy 20 th century hyper inflation that did not result from the disiocations of war or revolution. One major theme of our work is that the recent economic crisis in solivia is a reflection of political and economic conflicts in Bolivian society that have undermined the deveiopment process throughout this century. 


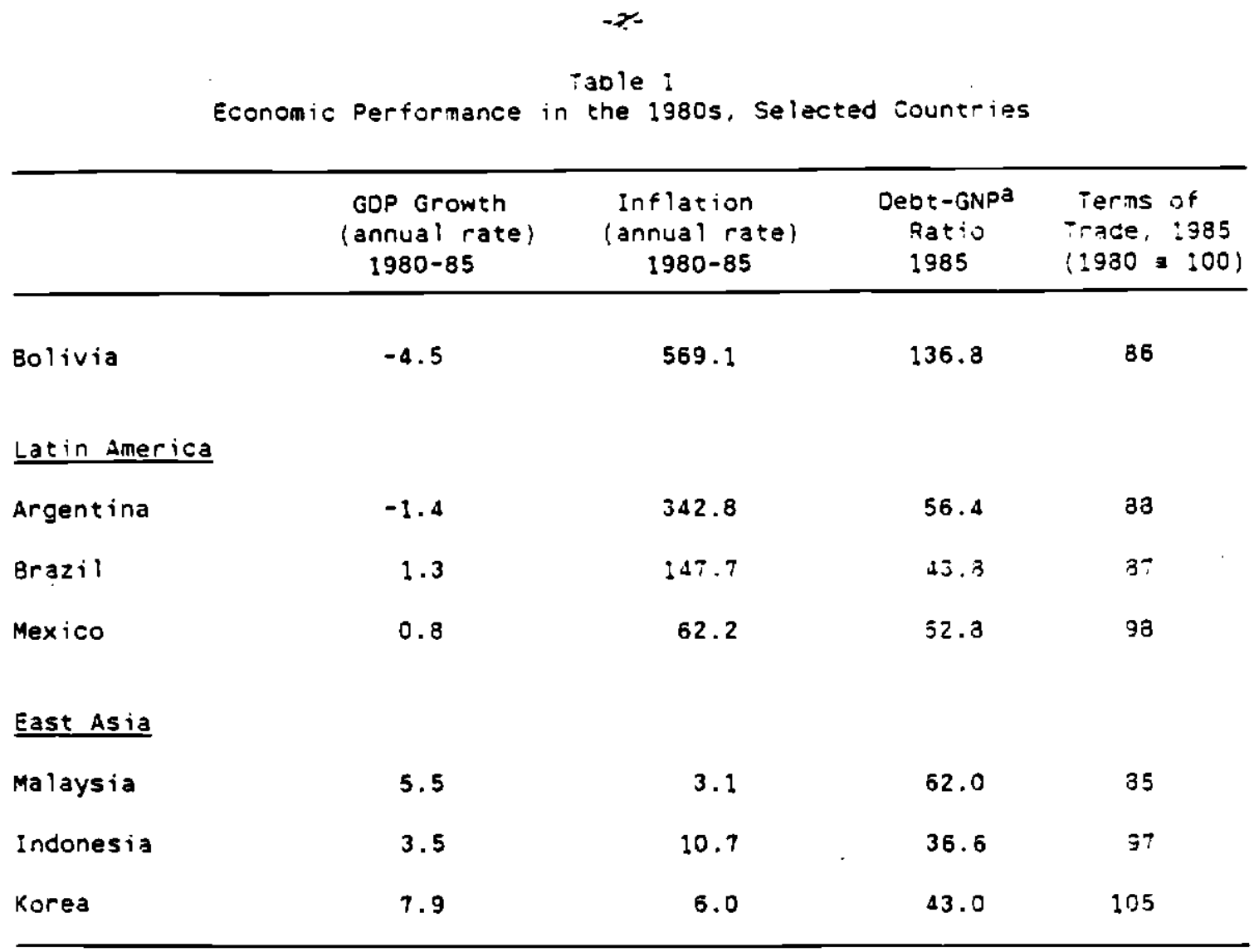

amedium and long-term debt, public and private.

Source: World Development Report 1987, Wor Id Bank. 
Table 2 gives a brief political chronology of Bolivia since the Revolution of 1952. The most striking aspect of the chronology is the instability of constitutional rule in the country. The Revolution of 1952 was led by of the National Revolutionary Movement, the MNR, which governed Bolivia for 12 years, winning elections in 1956 and 1960. The military toppled the civilian regime in 1964, and ruled without interruption until 1978. A period of political chaos followed during 1978-82, with a rapid alternation of military and civilian rule. Civilian rule was restored in 1982, with the accession to power of siles Suazo.

As in other Latin American nations, the alternation of power aiso reflected an alternation between populist and anti-populist politics. In 8olivia, however, this alternation has been particularly sharp. Generally. the military rule was anti-populist, and especially anti-labor. There was, however, a brief populist phase of military rule under General Torres in 1970-71, which coincided with the leftist military government in Peru under Velasco. The civilian governments have all drawn the ir leaders from the MNR, though the civilian governments have varied widely in their policies, with populist phases during 1952-56 and 1982-85, and conservative phases during 1956-64 and 1985 to the present.

The chronic political instability, and more specifically the swings between populist and anti-populist politics, reflect the deeper divisions in the Bolivian economy and society. Not only is Bolivia's distribution of income and wealth highly unequal, but the various sectors in Bolivian society are highly mobilized to do battle over their shares of income and wealth. Since the Revolution, all of the social factions have looked to the central 


\section{$-4-$ \\ Table 2 \\ Brief Political Chronologk, i352-1985}

Bolivian Revolution, carried out by Nationalist Revolutionary

Movement (MNR), under leadership of Or. victor Paz Estenssoro.

1952-1956 Presidency of Paz Estenssoro; sharp rise in inflation, to 178.8\%

in 1956.

1956-1960

Presidency of Siles Zuazo (MNR); economic stabilization under U.3.

and IMF supervision and finance.

$1960-1964$

Second presidency of Paz Estenssoro.

1954

Third presidency of Paz Estenssoro: Paz Estenssoro deposed in

military coup led by Barrientos Ortuno.

1964-1966 Co-presidency of Ovando Candia and Barrientos Ortuno.

1966-1969 Civilian presidency of Barrientos (dies in plane crash, April 1969).

1969 Vice President sile Salinas becomes president; deposed in coup by

Ovando Candia.

1970 Ovando Candia deposed by Gen. Miranda. Miranda deposed by

Gen. Juan Jose Torres.

1971 Torres rules left-wing radical government. Deposed in coup, jointly sponsored by military, FBS, and MNR.

1971-1973 General Hugo Banzer Suarez rules with MNR support.

1974-1978 Banzer presidency under military rule; MNR withdrawal from government in 1974 .

1979

Pereda becomes president in election marked by accusation of

fraud. Pereda deposed by Padilla, who calls for 1979 election. 
Table 2 (Cont.)

Brief Political Chronoiogy, 1952-:985

Election results in stalemate (no majority): Senate President Walter Guevara Arze serves as interim president. Guevara deposed

by Col. Natusch Busch; Busch fesigns in 15 days. President of Chamber of Deputies, Lidia Gueiler, becomes interim president. Electoral stalemate. Gueiler deposed in coup by Maj. Gen. Luis Garcia Meza.

Gen. Torrelio deposed in coup by Gen. Vildoso Calderon. Congress reconvenes; names siles suazo as president. 
government to satisfy their particular distributional agenda, and the battle for political power has also been a battle for a share of the national pie. The battle over shares has been particularly damaging since it has occurred in the context of a secular decline in the earnings of Bolivia's key mining sector. That decline not only made the need for a coherent development strategy particularly urgent, but also heightened the sense of desperation in the distributional battle.

The result, not surprisingly, has been a government stretched far beyond its fiscal capacity; an economic environment inimical to long-term investment; and an inability of the key political actors to settle on a sustained strategy for national economic development. The failure of economic development has taken its toll. Bolivia is the poorest country in South America, with a per capita income of about $\mathbf{\$ 5 0 0 ,}$ and the second poorest in the Western Hemisphere, behind Haiti. Between 1952 and 1985, GNP grew at the meagre annual rate of 2.4 percent.

In the next section of this paper, we extend this analysis as to why Bolivia has failed to develop a morkable strategy of long-term development. We then turn to an analytical chronology of the recent economic crisis, and highlight how the crisis has emerged from the longer-term failures that we have stressed. To understand the proximate economic determinants of the crisis, we highlight the critical linkages between foreign borrowing, the exchange rate, and inflation, that are key to understanding both the onset of the hyperinflation and debt crisis, and the progress that has been made since 1985 in overcoming the crisis. While major reforms have been begun by the present government, many of the deepest problems in Bolivian society that 
contributed to the crisis remain unresolved. We underline these areas of remaining difficulty, and discuss various policy options for addressing them.

\section{The Long-Term Problems of Bolivian Economic Growth}

Bolivia's problems begin with the inherent difficulties of growth in a landlocked mining econony centered in breathtaking, yet forbidding, terrain more than 14,000 feet sbove sea ?evel. Bolivia is a very large and sparsely populated country. Its area is greater than the combined areas of the United Kingdom, West Germany, and France, with a population of on iy 6 million. The country is divided geographically between the Andean highlands, where the mining industry is located, and the lowlands to the east, where petroleum products and commercial agriculture are situated. From the beginning of colonial development, Bolivia's political and economic center of gravity has been in the highlands. The secular decline of the mining sector has led in recent decades to a shift in economic and political activity to the East. This shift, which is the cause of significant political conflict, has been accelerated by the recent sharp crash of tin prices in October 1985 .

Bolivia's economy since the colonial period has been based on mining. first silver from the colonial period until the late 19th century, and then tin in the 20th century. With population centered in the highlands and neighborling valleys, transport costs are extremely high. Therefore, while it has been profitable for Bolivia to export minerals such as silver and tin that have a high value added per unit weight, and therefore a low share of transport costs per unit value, Bolivia has Deen unable to overcome the transport costs for almost any kind of manufactured product. The problem of 
transport costs was greatly exacerbated by Bolivia's loss of its littoral on the Pacific Coast, in the traumatic War of the Sea against Chile and Peru in 1879.

The requirenent of high value added per unit weight in Bolivian exports helps to explain Bolivia's only real diversification of exports in recent years: coca leaf derivatives (the precursors of cocaine) and petroleum products. Petroleum products, particularly natural gas exported to Argentina, can be carried out of the country by pipeline, while coca leaf can be profitably transported even if carried on a peasant's back. Taole 3 snows Bolivia's concentration of non-coca exports in recent years. Among Bolivia's measured exports (i.e., excluding coca), tin and petroleum products usually accounted for much more than half of total exports during the 1960s, 19705 , and 1980s. Coca exports in the 1980 s are generally estimated to equal the sum . of tin and natural gas exports.

Many of Bolivia's problems can be seen as the tragic playing out of the secular decline in the mining sector, a process that has been underway for at least half a century. (See Malloy [1970] for an authoritative account of 20th century Bolivian history before the Revolution, with an emphasis on the secular decline of the tin sector starting in the late 1920s.) Actually, Bolivia's first deep crisis came with the depletion of silver deposits and the fall of world silver prices at the end of the last century. Good fortune, however, pulled Bolivia out of $\mathrm{cr}$ is is when a boom in world demand for tin followed the development of the modern canning process. The apogee of modern Bolivian economic development relative to the neighboring countries was reached in the first two decades of the 20 th century, when tin was intensively 
Table 3

Relative Shares of Tin and National Gas in Total Exports of Bolivia

\begin{tabular}{lc}
\hline & $\begin{array}{c}\text { As } \begin{array}{c}\text { of Merchandise } \\
\text { Exports }\end{array} \\
\text { Year }\end{array}$ \\
\hline & \\
1952 & 59.9 \\
1953 & 64.2 \\
1954 & 55.2 \\
1955 & 56.0 \\
1956 & 55.1 \\
1957 & 53.9 \\
1958 & 50.1 \\
1959 & 68.2 \\
1960 & 71.0 \\
1962 & 89.7 \\
1963 & 89.5 \\
1964 & 80.6 \\
1965 & 80.5 \\
1966 & 70.2 \\
1967 & 58.5 \\
1968 & 58.9 \\
1969 & 57.3 \\
1970 & 52.0 \\
1971 & 58.4 \\
1972 & 61.3 \\
1973 & 57.2 \\
1974 & 48.0 \\
1975 & 48.1 \\
1976 & 62.4 \\
1978 & 72.0 \\
1979 & 65.9 \\
1980 & 63.6 \\
1981 & 68.3 \\
1982 & 73.5 \\
1983 & 77.6 \\
1984 & 86.1 \\
$1985(a)$ & 89.7 \\
\hline & \\
\hline &
\end{tabular}

(a) Estimate

Source: Central Bank of Bolivia. Boletin Estadistico. various issues. 
developed, and when export earnings provided the basis for a major extension of the country's. infrastructure, including roads and the railway system.

Tin lodes were increasingly exhausted in the 1920s, and Bolivia Jegan to lose export competitiveness with other producers. When tin prices collapsed at the start of the Great Depression, Bolivia becane the first country in that crisis to default on its sovereign foreign debt, in January 1931. Bolivia was also the last country in Latin America to settle these defaulted debts after Wor Id. War II.

The collapse of tin undermined both the economy and the political system, known as the Rosca, which was managed heavily in favor of the three tin magnates, Patino, Hochschild, and Aramayo. The public finances, which relied heavily on tin exports and international trade generally, were gravely weakened, and the financial problems generally undermined the central government. Thus, the period between 1931 and the Revolution of 1952 was an era of political uncertainty and unrest. Bolivia lost the bloody and costly Chaco War to Paraguay in the mid-1930s, an experience which heightened the political mobilization of workers and the middle classes unhappy with the leadership of the oligarchy. A military government with a mixed fascist and revolutionary orientation came to power in 1943, but was deposed in 1946 . The oligarchy regained control in 1946, but was swept aside by the Revolution of 1952.

The leaders of the Bollvian Revolution of 1952 drew inspiration from the Mexican Revolution, and from Mexico's Institutional Revolutionary Party (the PRI), In the formation and policles of the Bolivian National Revolutionary Movement (the MNR). The experlence under the Rosca had thoroughly discredited 
private wealthholders as a class capable of leading national development. The Revolutionary leaders looked to the public sector as an engine of growth that would be more broadly based and equitable. They put in place an economic system, which can broadly be called state capitalism, which assigned the bulk of capital formation to the public sector, both for infrastructure and for industrial production in state enterprises. The leading state enterprises were COMIBOL, the national tin company, and YPFB, the state petroleum company. It should be stressed that the reliance on the state sector was guided by political considerations as we 11 as by an ideology of economic development. The revolutionary movement, after toppling the oligarchy, was hardly interested in returning power to a small class of wealthholders. Indeed, given Bolivia's highly unequal income distribution, the problems of establishing a political equilibrium together with mass participation (indeed mass political mobilization) were evident. A large state sector was viewed as providing a political answer to the distributional bind. As seen in Table 4 , Bolivia's income distribution remains, despite the Revolution, highly unequal. The Revolution did succeed, particularly through land reform, in raising the income share of the poorest 20 percent of households above the shares found in several other Latin American countries.

Despite the great variation of governments after 1952, one aspect of the model of state capitalism remained fairly constant. Whether the government was of the populist left, as under the military leader General Torres in 1970-71, or of the right, as under the military regine of General Hugo Banzer during 1971-78, the state was looked to as the guiding force of development. As shown in Table 5, a large fraction of total national investment, generally 


$$
-12-
$$

Table 4
Income Distribution in Selected Countries

\begin{tabular}{lcccc}
\hline & Year & Bottom 20\% & Top 20\% & $\begin{array}{c}\text { Ratio, } \\
\text { Top Botion }\end{array}$ \\
\hline Bolivia & 1970 & 4.0 & 59.0 & 14.8 \\
Latin America & & & & \\
\hline Argentina & 1970 & 4.4 & 50.3 & 11.4 \\
Brazil & 1972 & 2.0 & 66.5 & 33.3 \\
Mexico & 1977 & 2.9 & 57.7 & 19.9 \\
East Asia & & & & 16.0 \\
Malaysia & 1973 & 3.5 & 56.1 & 7.5 \\
Indonesia & 1976 & 6.6 & 49.8 & 7.3 \\
Korea & 1976 & 5.7 & 45.3 & 3.7 \\
Taiwan & 1976 & 9.5 & 35.0 & \\
\hline
\end{tabular}

Source: World Bank; national sources for Taiwan 
Table 5

Public and Private Participation in the Gross Capital Fixed Formation

\begin{tabular}{|c|c|c|c|c|c|c|}
\hline \multirow[b]{2}{*}{ Year } & \multicolumn{2}{|c|}{ Public } & \multicolumn{2}{|c|}{ Private } & \multicolumn{2}{|c|}{ Total } \\
\hline & Amount & $\bar{q}$ & Amount & $\overline{8}$ & Amount & $\%$ \\
\hline 1958 & 203.0 & 42 & 206.0 & 58 & 489.0 & 100 \\
\hline 1959 & 213.0 & 40 & 313.0 & 60 & 526.0 & 100 \\
\hline 1960 & 281.2 & 44 & 355.8 & 56 & 637.0 & 100 \\
\hline 1961 & 239.1 & 45 & 292.2 & 55 & 581.3 & 100 \\
\hline 1962 & 452.0 & 54 & 382.7 & 46 & 834.7 & 100 \\
\hline 1963 & 576.0 & 62 & 348.3 & 38 & 924.3 & 100 \\
\hline 1964 & 570.1 & 60 & 387.6 & 40 & 957.7 & 100 \\
\hline 1965 & 451.1 & 43 & 599.7 & 57 & 1.050 .8 & 100 \\
\hline 1966 & 478.3 & 50 & 470.8 & 50 & 949.4 & 100 \\
\hline 1967 & 581.6 & 50 & 574.1 & 50 & $\therefore .155 .7$ & 100 \\
\hline 1968 & 929.0 & 52 & 041.0 & 40 & 1.770 .0 & 100 \\
\hline 1969 & 910.5 & 59 & 633.4 & 41 & 1.543 .9 & 100 \\
\hline 1970 & $1,002.0$ & 56 & 790.0 & 44 & 1.792 .0 & i00 \\
\hline 1971 & 1.170 .0 & 40 & 781.0 & 40 & 1.951 .0 & 100 \\
\hline 1972 & $1,548.0$ & 59 & 1.075 .0 & 41 & 2.823 .0 & 100 \\
\hline 1973 & 1.690 .0 & 37 & 2.829 .0 & 83 & $4,519.0$ & 100 \\
\hline 1974 & $2,199.0$ & 34 & 4.351 .0 & 56 & $6,550.0$ & 100 \\
\hline 1975 & $3,711.0$ & 41 & $5,344.0$ & 59 & $9,055.0$ & 100 \\
\hline 1976 & 5.949 .0 & 56 & 4.736 .0 & 44 & $10,655.0$ & 100 \\
\hline 1977 & $7,930.0$ & 64 & $4,484.0$ & 36 & $12,414.0$ & 100 \\
\hline 1978 & $10,216.0$ & 66 & $5,180.0$ & 34 & $15,396.0$ & 100 \\
\hline 1979 & $8,928.0$ & 58 & 6.378 .0 & 42 & $15,306.0$ & 100 \\
\hline $\begin{array}{l}1980 \\
1981\end{array}$ & 9.767 .0 & 50 & 7.361 .0 & 42 & $17,328.0$ & $\begin{array}{l}100 \\
100\end{array}$ \\
\hline 1982 & & & & & & 100 \\
\hline
\end{tabular}

Source: Ministry of Planning and Central Bank of Bolivia 
more than half in the 1960s and 1970s, was invested directly by the public sector. This predominant role of the state is, of course, not unusual for late developers, as was elegantly demonstrated by Gerschenkron many years ägo in the case of the European latecomers. And as stressed in Sachs [1987] the state has played a very large, and apparently successful, role in spurring economic development in Japan, Korea, and Taiwan. What has been distinctive in the Bolivian case, however, has been the fundamental disjunction between the weak capacity of the state on the one hand, and the responsibilities invested in the state on the other.

The whole concept of more equitable growth through a large state sector collapsed in a mass of inconsistencies over the thirty years between the revolution and the onset of the Bolivian hyperinflation. Ouring the post-Revolution period, leftist leaders were always too weak politically to satisfy their redistributional aims. To the extent for instance that they aimed to raise public sector salaries or to increase public sector investment and employment, they lacked the capacity to tax income and wealth necessary to finance the larger state sector. If necessary, the Bolivian army was prepared to intervene to forestall populist or redistributionist actions, as it did in 1971. For these reasons, leftist or populist leaders have been constantly forced to rely on inflationary finance or foreign aid and foreign borrowing to carry out their distributional and developmental goals. The first high inflation in Bolivia came in the wake of the Revolution, and the second came. with the left-wing government of siles suazo in 1982 .

Leaders on the right, such as Barrientos and Banzer, were not interested to linit the power of the state. but rather to use the state to satisfy a 
different agenda. While governments on the left sought redistrioution through higher wages and a larger role for public-sector workers, governments on the right sought instead to bolster favored segments of the private sector through generous government subsidies. Governments of the left have generally paid for higher public salaries through printing money (i.e. the inflation tax) or through foreign borrowing, since they have been forestalled from raising taxes. Governments on the right, on the other hand, have rejected higher taxes outright, and have instead sought to finance the government through a reduction of public sector wages (often with overt repression of labor), and also through foreign borrowing. Note one common theme of both types of governments: let the foreigners pay!

The conflict over income distribution continues to have a number of profound effects on economic policy and economic performance. The first effect that we have noted is fiscal indiscipline, since powerful high-income groups veto the income and wealth taxes that would be needed to finance a large public sector. A second effect is the deep politicization of almost all instruments of economic policy. There are few economic policy tools in Bolivia that are judged mainly on the basis of efficiency rather than distribution. Exchange rate changes, for example, have been typically avoided in Bolivia until currency overvaluations reach absurd proportions, for fear of a resulting distributional battle. Similarly, public sector prices have often been stuck at levels far below market clearing rates, for the same reason, despite the often devastating fiscal consequences. A third effect of the continuing battle over income distribution is the uncertainty for private investment spending that is created by the alternation between leftist and 
rightist regimes with widely varying agendas. A fourth effect has been the degeneration of politics into a fierce battles of the "ins" versus the "outs." With the state viewed as an instrument of redistribution, succeeding governments came to view the public purse and the public enterprises as private slush funds, to be used for personal gain or political patronage. Malloy [1987] has termed this condition "neopatrimonialism."

\section{Origins of the Debt Crisis}

As shown in Table $\dot{6}$, Bolivia's external deot rose aramatically in the 1970s, mostly during the Banzer era. Bolivia's rapid accumulation of external debt in the 1970 s reflected three forces at work. Part of the foreign borrowing financed a plausible attempt to generate a more diversified export base through various investment projects. Some of these projects, such as natural gas exports to Argentina, proved successful. Others, such as investment in erude petroleum production, proved to be failures. Less benignly, the foreign borrowing also reflected an attempt to finesse the internal distributional conflict on borrowed money and borrowed time. The government did not attempt to raise taxes (and indeed rejected a detailed tax reform proposal of the Musgrave Commission). Third, and most perniciously, some of the foreign borrowing had the purpose and effect of enriching a narrow set of private interests via the public sector's access to foreign loans. similarly, an overvalued exchange rate, maintained through foreign borrowing, became a channel for capital flight for the wealthier individuals.

The economic record of the Banzer years look quite good when taken in isolation. Bolivian GOP growth averaged 5.4 percent per year, which was far 
Table 5

Bolivian External Debt, 1970-1985

\begin{tabular}{|c|c|c|c|c|c|c|c|c|}
\hline Smillions & 1970 & 1975 & 1980 & 1981 & 1982 & 1983 & 1984 & 1985 \\
\hline $\begin{array}{l}\text { Total debta } \\
\text { (MLT Public and } \\
\text { Publicly Guaranteed) }\end{array}$ & 481.7 & 824.4 & 2228.6 & 2679.2 & 2769.1 & 3105.1 & 3203.5 & 3259.3 \\
\hline Debt/GNP (\%) & 46.3 & 46.2 & 78.1 & 89.3 & 102.0 & 111.5 & $1: 5.3$ & 124.3 \\
\hline Debt/Exports (\%) & 232.6 & 166.7 & 213.1 & 262.3 & 301.5 & 345.4 & 377.8 & 441.9 \\
\hline
\end{tabular}

apebt outstanding and disbursed, medium and long-term maturities, on public and publicly guaranteed debt.

Source: World Debt Tables, World Bank, 1986-87 Edition. 
above the average of 2.4 percent during the whole period 1952-1985. Prices were rather stable except in 1974, following a major devaluation of the 8olivian Peso. Investment as a share of GNP reached historical highs, as did government revenues relative to GNP, though the gap between government expenditures and government revenues widened. In an era of easy foreign finance, however, the gap was readily filled by eager foreign bankers. Few observers at the time realized the precariousness of the Banzer boom, built as it was on a temporary comnodity boom, easy access to foreign finance, and a narrow political base.

Banzer's rule lasted for seven years, an extraordinary stretch by Bolivian standards. For three years, Banzer ruled with the support of both leftist and rightist political parties. As Malloy [1987, p.103] indicates, Banzer jettisoned these parties in 1974 when he recognized that "they were rump factions who represented little more than cliques whose primary purpose was to lay claim to public-sector jobs." From 1974 to 1978 , Banzer ruled with the support of private-sector business, the military, and some technocrats. Because of the booming economy, Banzer enjoyed the support of the urban middle classes, and even some favored labor groups such as the railway workers, but faced continued strong opposition from most of organized labor, and the leftist parties.

Another important dimension of support and opposition to Banzer was regional. The eastern part of the country, and especially Banzer's home province of Santa Cruz, provided strong support and were major beneficiaries of Banzer's policies. Groups in this region were favored with grants of property rights over public lands, and with generous subsidized credits. An 
important illustration of how the government distributed public revenues to private supporters is the case of loans for large-scale cotton production in the Santa Cruz region, made by the government Agricultural Bank (Banco Agricola Boliviano) between 1972 and 1975. Tens of millions of dollars were loaned to a small number of large landowners during an incipient cotton boom. The Bolivian producers sold their Erops forward on world markets, but then tried to renegotiate when the spot market prices rose above the forward contract price. They failed in the renegotiations, and in the end, much of the cotton remained undelivered. The growers quietly defaulted on the Agricultural Bank loans and the government absorbed the losses with no attempt to collect or to foreclose on any property. To this day, the bad cotton loans have undermined the solvency of the Agricultural Bank.

In 1975, the Banzer regime announced a five-year development plan which. encapsulated the governing philosophy. The plan aimed at export promotion led by state investment. The public sector was targetted with 71 percent of total investment over the period, focussed heavily on hydrocarbons, mainly in the Santa Cruz region. Financing of the plan was to rely on the profits from petroleum exports, which in the event never materialized, and on foreign borrowing, which did. Most of the plan however was never implemented.

In 1977 and 1978, General Banzer faced growing pressure from the Carter Administration for a return to denocracy. An election was called, but was annulled after charges of massive fraud. When Banzer then tried to remain in office, he was ousted in a coup. There ensued a four year period of intense political instability, with several interim presidents, coups, and deadlocked - lections, producing in all nine different heads of state between Banzer and siles. 
Bolivia reached its political nadir in 1980 and 1981, when General Garcia Meza deposed the interim president Lydia Guiler. The Garcia Meza regime was deeply implicated in the burgeoning cocaine industry, and therefore never received international support, except for the backing from the similarly corrupt and violent military regime in Argentina. Capital flight reached new highs in the period, with errors and omissions in the balance of payments in 1980 and 1981 totalling s590 million, or about 10 percent of 1980 GNP. The commercial banks stopped all lending, and negotiated an emergency rescheduling agreement which was soon defaulted upon. The rest of the international community also ceased new lending, except for two important loans from the Argentine regime.

Not one of the heads of state during this chaotic period had the political backing to address the acute economic problems facing the country. Banzer's strategy of foreign borrowing had run its course, with insufficient export earnings and government revenues to show for it. The various governments following Banzer during 1978-82 were in no position to raise taxes or enforce economic austerity, and so they resorted to printing money when the flow of foreign money changed from net inflow to net outflow. On top of the problem of obtaining fresh credits, comodity prices started to slide in 1981 . and interest rates on the existing international loans soared. By October 1982, when the Siles Suazo government came to power, the econony was in a sharp dowmward slide. Real GNP had declined by an estimated 0.9 percent in 1981 and by 8.7 percent in 1982 . The price level had risen by 308 percent in the twelve wonths preceding siles' accession to power. 


\section{The March to Hyperinflation}

It is important to appreciate the political implications of siles'

accession to power in 1982 . The new administration represented the first elected government in 18 years, so that pent-up social and economic aspirations were sure to boil over early in the term. Siles represented the left wing of the MNR, and governed in a coalition with various leftist parties, including the Communist Party of Bolivia. In the early phase of the administration, organized labor gave support to the new government, but only in return for significant wage increases. Ultimately, when the financially strapped government was unable and unwilling to grant wage increases to keep ahead of the accelerating inflation, organized labor turned bitterly against the government. General strikes by organized labor in 1984 and $1985 \mathrm{kill}$ led the final two stabilization attempts of the siles administration.

The hyperinflation under siles was not so much a result of an explosion. of new spending as the inability to restrain spending in the face of falling foreign loans, falling tax revenues, and higher debt service paynents abroad. The coalition members were never able to agree on policies to restrain spending, while the government's right-wing opponents in the Bolivian Congress rejected all proposals to broaden or even stabilize the tax base. At a fundamental level, moreover, the coalition government failed to realize that the deepening $\mathrm{Cr}$ isis was an indictment of the system of state capitalism itself, and especially of the financial liditations of that system. To the end, the Siles administration defended the logic of a large state enterprise sector, even as $1 t$ tried to squeeze key state enterprises in order to support the finances of the rest of the government. 
The hyperinflation and debt crisis developed as Bolivia's net resource transfers from the rest of the wor ld turned negative in 1982 . Seignorage financing (i.e. printing money) substituted for the decline in foreign resource flows. Table 7 demonstrates this shift in foreign resources for a subset of loans, the nedium and long-term public or publicly guaranteed loans. We see that for 1979 through 1981. new net borrowing by the public sector exceeded the interest payments on the public debt. In 1982, nowever, net new lending plummetted, so that the transfer of resources to Bolivia Inet new loans minus interest payments) turned sharply negative. As a percent of GNP, net resource transfers on the loans in Table 4 shifted from 6.2 percent of GNP in 1980 , to 3.1 percent of GNP in 1981 , to -3.4 percent of GNP in 1982 , and to -6.9 percent of GNP in 1983 .

The jump in seignorage, which fueled the hyperinflation, is the mirror image of the declining net resource transfer from abroad. As the government devoted an increasing share of resource to foreign debt servicing, it resorted to printing money to finance the balance of its domestic spending. Figure 1 shows this pattern clearly. Seignorage jumped in mid-1982, several months before silés' term began. Aside from seasonal spikes in seignorage in the fourth quarter of most years lassociated with a Christmas wage bonus for public-sector worker), seignorage remained at a high plateau of about 12 percent of GNP annualiy until stabilization was achieved in late 1985 . Note that the decline in net resource transfers (a shift of about 10 percent of GNP), and the rise in seigr.orage, are of about the same magnitude.

The relative constancy of government seignorage does not reflect a stable level of government spending, taxes, and monetary emission. Rather, the 
Taole 7

Bolivia's Debt Servicing of Medium and Long-Term Public Sector Debt

\begin{tabular}{|c|c|c|c|c|c|}
\hline & 1980 & 1981 & 1982 & 1983 & 1984 \\
\hline Net Interest Payments & 163.9 & 171.0 & 130.9 & 172.8 & 201.3 \\
\hline Official Creditors & 42.8 & 50.3 & 66.2 & 64.7 & 166.2 \\
\hline Private Creditors & 121.1 & 120.7 & 114.7 & :08.: & 35.2 \\
\hline Net New Lending & 341.9 & 263.2 & 38.5 & -18.0 & 50.5 \\
\hline official Creditors & 191.0 & 163.9 & 103.0 & 13.5 & 63.3 \\
\hline Private Creditors & 150.9 & 99.3 & -14.4 & -31.5 & -2.9 \\
\hline Net Resource Transfer & 178.0 & 92.1 & -92.2 & -190.8 & -140.8 \\
\hline official Creditors & 148.2 & 113.6 & 36.8 & -51.3 & -102.9 \\
\hline Private creditors & 29.8 & $-21 \cdot 4$ & -129.1 & -139.5 & -37.3 \\
\hline $\begin{array}{l}\text { Net Resource Transters } \\
\text { Total, } * \text { of GNP }\end{array}$ & 6.2 & 3.1 & -3.4 & -6.9 & -5.1 \\
\hline
\end{tabular}

Source: World Bank World Debt Tables, 1985-1986 Edition. 


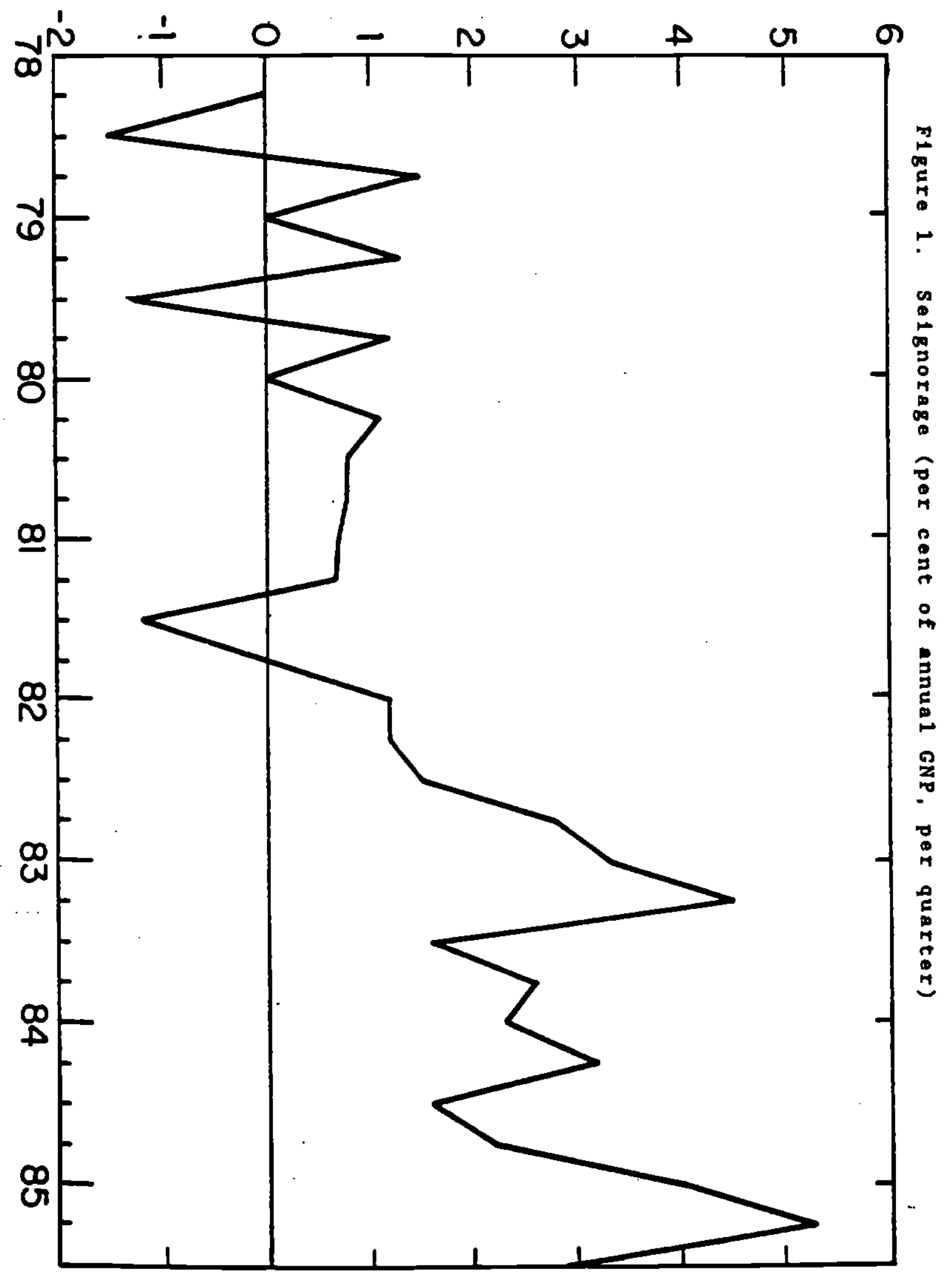


constancy of the seignorage collection hides a process of fiscal collapse in which tax revenue collections all but disappeared, while government spending (particularly on public investment projects) was cut back sharply in a vain attempt to catch up with the moving target of falling tax collections.

Meanwhile, the monetary emission prompted repeated and accelerating depreciations of the exchange rate, which then fed into inflation. As inflation accelerated, the demand for real money balances fell, so that a constant rate of seignorage collection as a percent of GNP was associated with an accelerating inflation and a falling level of real money balances.

Government revenues in Bolivia in the early 1980 s relied heavily on three main forms of taxes: internal taxes (mainly sales, property, and income taxes); taxes on trade (mainly tariff collections); and taxes on hydrocarbons and minerals (mainly paid by COMIBOL and YPFB). As shown in Figure 2 , each of these taxes plummeted as a percent of GNP. Overal1, revenues of the central administration (the TGN) fell from more than 9 percent of GNP in 1980 to just 1.3 percent of GNP in the first nine months of 1985. The proportion of TGN expenditures backed by TGN revenues fell from 65.5 percent in 1979 to just 6.9 percent in the first nine months of 1985 .

As is well known from the studies of oliviera [1967] and Tanzi [1977], inflation itself can be a major factor in undermining the government revenue collections. In Bolivia, several particular institutional factors were at work. With income taxes, simple lags in collection reduced the real value of collections almost to nothing by 1985. Similarly, property taxes and several excise taxes were stated in specific, rather than ad valorem, terms. Thus, as the price level rose, the real value of the tax collections fell. Tariff 


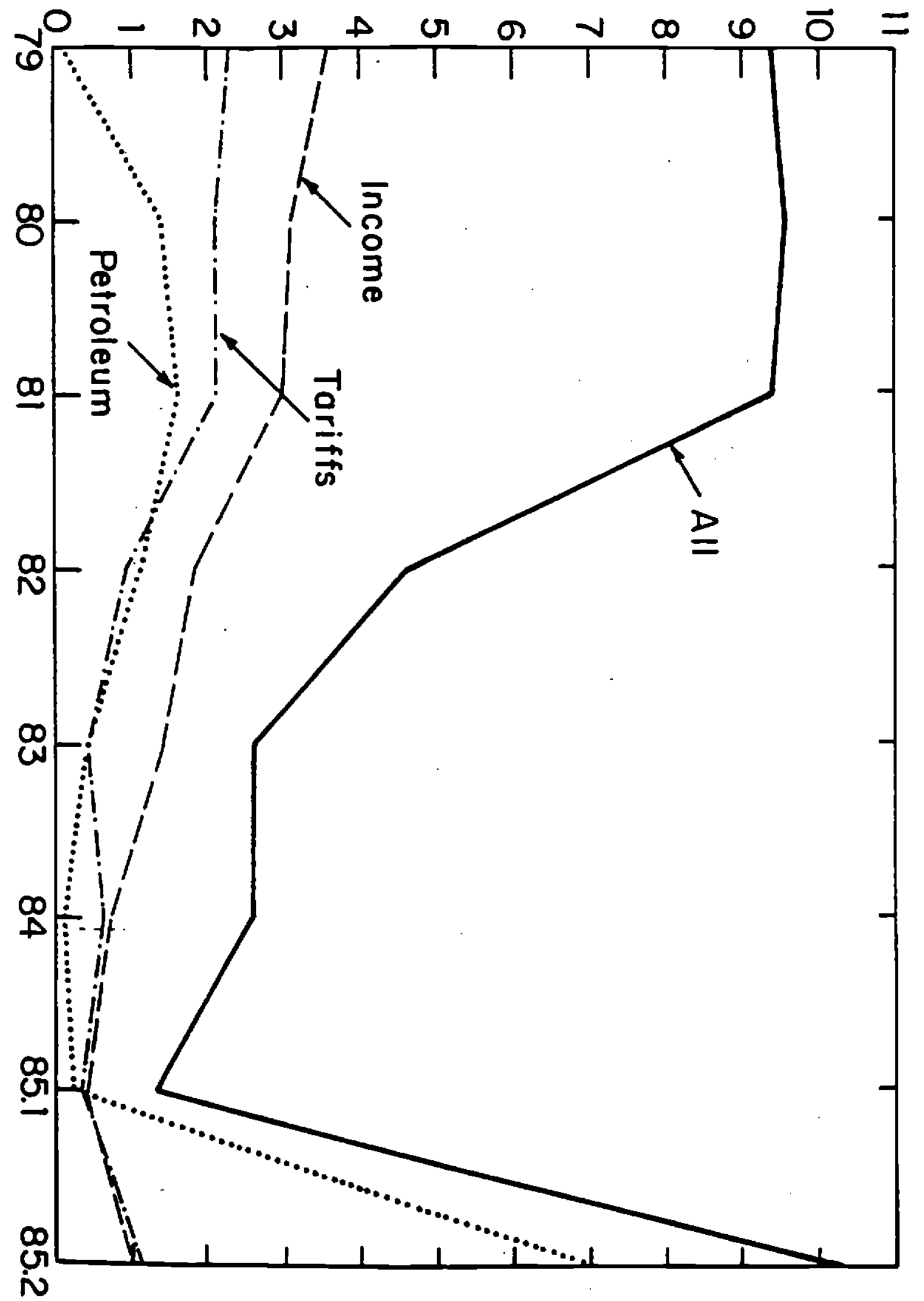


revenues declined for several reasons. The downturn in economic activity reduced imports, and therefore tax collections. Equally important, the official exchange rate was persistently overvalued relative to the black market rate. This had the effect of encouraging smuggling, on which tariffs are typically not collected. Even when goods were imported legally, however, the tariff in pesos was collected on the basis of the official exchange rata, and therefore the real value of the tariff collections was substantially reduced. The taxes on mining and hydrocarbons were similarly squeezed. The overvalued exchange rate reduced the profitability of the state enterprises in these sectors, and they therefore paid their taxes to the central government on a sporadic basis only. Indeed, the central bank made large transfers to the state enterprises to keep them functioning despite the squeeze on their operating revenues.

It is more difficult to offer an account of spending patterns by the central government during the hyperinflation period, because of serious data limitations. The following major points seem clear, however. There was a sharp squeeze on public investment spending rather than wages and salaries as the siles government attempted to cope with the growing fiscal crisis. Union opposition successfully forestalled any serious attempts to reduce public sector real wages or public employment, until the end of the hyperinflation. Until the spring of 1984, the government squeezed internal spending and relied on monetary eaission to aake room for interest servicing on the foreign debt. In the spring of 1984 , the government finally quit debt service payments on the government debt to the commercial banks. By this time, ironically, the rising inflation had so ravaged the tax system that even with the suspension 
of interest payments, the deficit on a cash-bas is remained enormous, so that the resort to seignorage finance was hardly slowed.

There are many particular features of public finance in this period that help to give a deeper insight into the dynamics of the hyperinflation. In a fooihardy attempt to restrain inflation, the government resorted continually to ineffectual price controis, overvalued and multiple exchange rates, and other forms of intervention. These policies had no effect on the general price level, but they frequentiy threatened the solvency of private and public firms. In response, the government would typically find some indirect way to compensate the firms for the intervention measures, and thus the direct price control measure would show up as an indirect fiscal subsidy, adding to the government's need for inflation finance.

While the hyperinflation was a disaster for the economy and 8olivian society as a whole, many well-connected rent-seeking individuals made considerable fortunes in the course of the hyperinflation. Anybody with access to official foreign exchange from the central bank could become wealthy almost instantly during the period, by purchasing cheap dollars at the central bank and selling them at a several hundred percent profit in the black market. Similarly, commercial bankers, who took deposits at zero interest and lent money at high nominal interest rates, shared in the government's seignorage gains. Moreover, the government extended large amounts of low interest loans during the pertod, often to politically powerful landowners, which effectively becase grants as a result of the inflation. Price controls on public sector goods, including flour and petroleum products, generated opportunities for lucrative smuggling operations. All of these opportunities for gain provided 
a powerful constituency of those who wanted to see the hyperinflation continue.

\section{The Stabilization Process}

The inflation under siles went from annual rates of several hundred percent in 1982 and 1983 to several thousand percent in 1984 and 1985 . According to Cagan's classic definition of hyperinflation (price increases exceeding 50 percent per month), the true hyperinflation began in May 1984 and ended in September 1985, upon the accession to power of the Paz Estenssoro government. It should be noted that siles tried severz? times to implement a comprehensive stabilization program (during November 1982, November 1983, April 1984, August 1984, November 1984, and February 1985), but in each of these cases, some combination of siles' political opponents in Congress, and his ostensible "allies" in organized labor, toroedoed the adjustment efforts.

The successful stabilization program was carried out by the newly elected center-right government of Paz Estenssoro. The government came to power in rather inauspicious circumstances, after another election which failed to produce a clear majority for one of the candidates. The program of the Paz administration was unveiled only three weeks after the government came to power. The program was remarkably wide ranging, and indeed radical, encompassing not only plans for macroeconomic stabilization, but also for trade liberalization, administrative and tax reform, and deregulation and privatisation in the domestic market. The so-called "New Economic Policy" was nothing less than a call to dismantle the system of state capitalism that had prevailed over the previous thirty years. 
The fiscal part of the program was to operate on five fundamental bases: - a stable unified exchange rate backed by tight fiscal and monetary policies:

- increased public sector revenues, via tax reform and improved public sector prices:

- a reduced public sector wage bill, through reductions of employment in state enterprises (particularly COMIBOL) and reduced rates of real compensation;

- an effective elimination of debt servicing, through a combination of rescheduling with official creditors, and a unilateral suspension of payments to private creditors until a more fundamental debt settlement could be arranged;

- a resumption of concessional foreign financial assistance, from foreign governments and the multilateral institutions.

The leading trade union organization, which had opposed and mobilized against similar, indeed far less dramatic, policy packages under siles, called for a general strike in opposition to the program. But after three years of accelerating inflation, and the sense of chaos in eably 1985, the new government clearly had the upper hand. A temporary state of siege under the constitution was declared, and the strike was quickly broken.

The fiscal measures, combined with a buildup of internal arrears by the central government, were sufficient to obviate the need for fiscal credit from the central bank to support government spending. The exchange rate stabilized almost immediately, and with a stable exchange rate, the price level stopped rising. As shown in Figure 3 , the remarkable break in the hyperinflation 


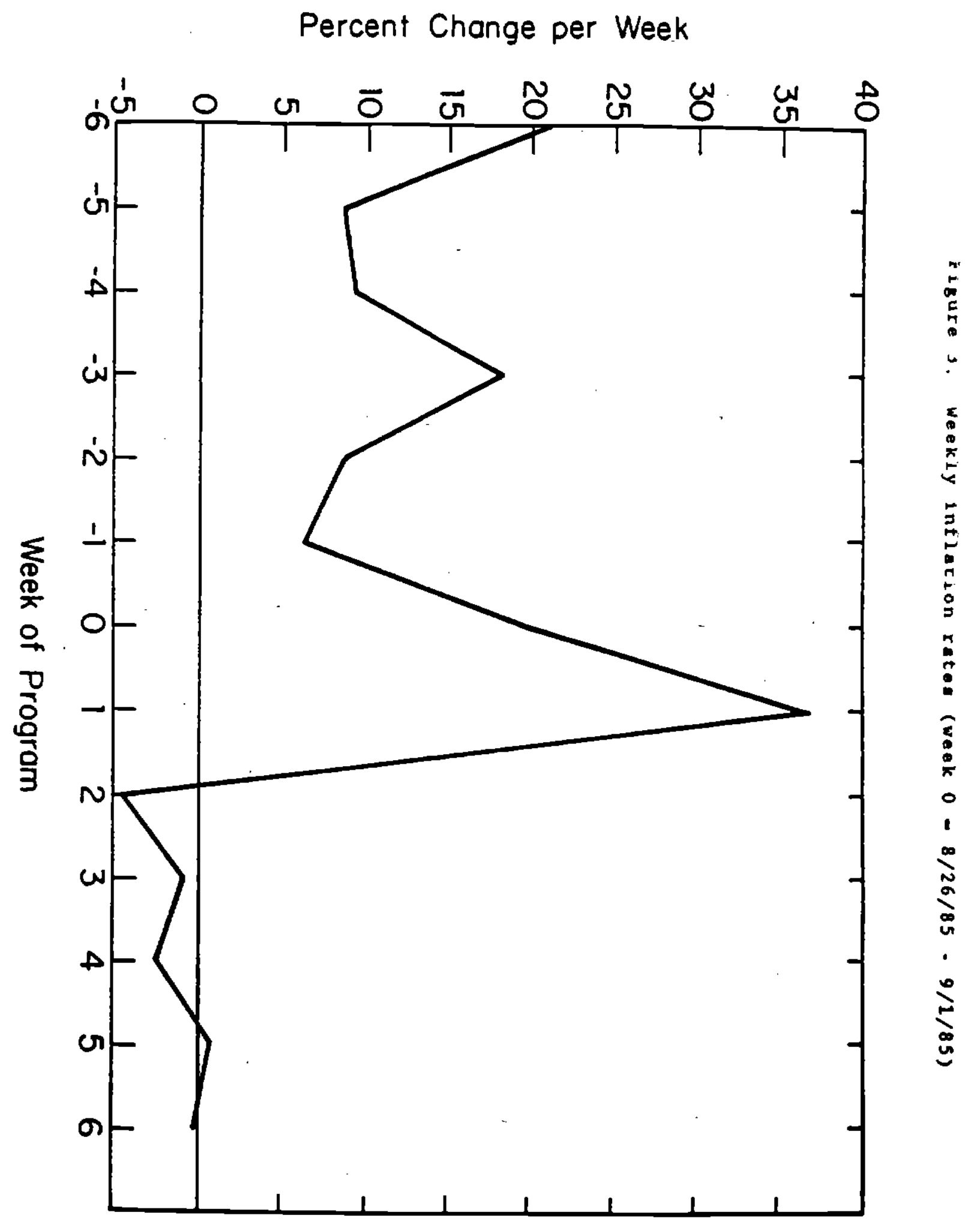


began no more than one week atter the inception of the program! Inflation fell from a rate of more than 50 percent per month to price stability aimost immediately. The key to price stability proved to be a stable unified exchange rate, protected by tight fiscal and monetary policies. When the government deviated from that policy temporarily at the end of 1985, the high inflation quickiy surged again, but this tine it was stopped by a reassertion of fiscal discipline. From February 1986 to July 1987 , the inflation rate has averaged only 10-15 percent at an annual rate, one of the lowest inflation rates in Latin America.

One key aspect of the stabilization should be highlighted, to contrast. the case of Bolivia with those of Argentina, Brazil, and Peru. The 3olivian stabilization was highly orthodox with respect to monetary, fiscal, and pricing policies (though it was "heterodox" in its continued suspension of foreign debt payments). The stabilization program eschewed all wage and price controls as part of the anti-inflation effort, and indeed freed many controis at the inception of the program. It is likely that the hyperinflation had obviated any need for price controls as part of the anti-inflation effort. since the high inflation rates had eliminated all vestiges of long-term contracts, and therefore all vestiges of inertial inflation. Peso prices were basically being set at the end of the hyperinflation by converting dollar prices of goods into pesos at the spot market exchange rate. Thus, by stabilizing the exchange rate, the inflation rate was immediately stabilized to the prevailing rate of dollar inflation in world markets.

In reality, stabilization is a cumulative process, not an event. While prices quickly stopped rising, fiscal reform has been underway for two years, 
and the results are still unsatisfactory in major areas. The government nas had to proceed gradualiy along three major dimensions: Li; a reouiloirg of ihe national tax system, which had virtually collapsed by the end of the hyperinflation: (2) a reestablishment of normal relations with the government's various creditors, both internal and external; and (3) a restructuring of the public sector, to provide for a nore durabie so:itis to the fiscal crisis. Let us consider each of these in turn.

The restoration of a stable revenue base has proceeded in stages. The immediate and crucial actions of the Paz government were the raising of public sector prices and the unification of the exchange rate. In addition, some back taxes on hydrocarbons and tin were also collected at the outset of the stabilization program, to give the government some fiscal breathing space. Eight months later, the Bolivian Congress approved the government's tax retorm measures, which most importantly instituted a national value added tax of 10 percent. (Characteristically, the Congress postponed a tax on land wealth until 1988.) Implementation of the tax measures has been slow and uneven however, despite the formation of a new Ministry of Taxation. Administrative difficulties and political pressures from powerful groups have slowed the introduction of the new taxes.

Even more difficult, perhaps, has been the process of extricating the government from an enormous overhang of national debt. The Banzer government bequeathed a highly indebted public sector to siles, and the siles administration bequeathed a truly bankrupt public sector to Paz. Not only mere payments to all international creditors, both public and private, deeply in arrears by 1985 , but payments internally to various creditors were also in default. 
With respect to the international creditors, the government has sought substantial debt relief. For foreign governments that are creaitors of Bolivia, the government has rescheduled payments via the Paris Club. For multilateral creditors, including the world Bank and the imf, the government has becone current on payments, partly on the view that it stands to receive net resource inflows from the multilateral agencies. For private foreign creditors, mainly the commercial banks, the government has maintained a suspension of interest payments, and has been negotiating with the creditors for a "fundamental" solution to that part of the deot, via some mechanism of debt repurchase and cancellation.

The indebtedness problens are also severe internally, thougn measured internal debt is rather low. The siles administration failed to honor many internal obligations, to private suppliers as well as to regional corporations and other quasi-official entities. In many cases, promises for transfer payments were made by the siles government as a way to buy time or support, in full knowledge that the obligations could not be met. Thus, as revenues under the current government have increased, the pressures for renewed payments on various outstanding commitments have also risen. The government has been forced into negotiations on many of these ostensible claims, and each negotiation has generated a domestic political battle that threatens the fragile fiscal equilibrium.

Since the Bolivian government does not have the benefit of a bankruptcy proceeding that would partially cancel its outstanding debts once and for all, it will continue for many years to be buffeted by various claimants. Each creditor has the incentive to fight bitterly for full payment on its claims, 
and thereby to beat the other claimants, even though all creditors weli recognize the impossibility that the total sum of claims can be met. This "grab race" among the various creditors, which is precisely what is blocked by formal bankruptcy proceedings, leads to a constant and bruising political battle between the government and its various creditors, a battle which continues to put the government at political jeopardy.

The third part of the stabilization process cited earlier is the reform of state administration. Under Banzer and Siles, the central government had grown to extravagant proportions, since much of the government had degenerated into a patronage machine. This bloated and unwieldy state mechanism was aiready on the verge of collapse before the end of 1985, when suddenly tin and petroleum prices plummeted on world markets. To preserve fiscal balance, the government had to launch a bruising, indeed brutal, battle to reduce the employment in COMIBOL and YPFB. Although fiscally necessary, the results are stunning, and indeed reflect a social tragedy. COMIBOL has reduced its employment from about 30,000 workers in 1985 to just 7,000 as of 1987 . Many of these workers are unemployed, or marginally employed, or have gone to the coca growing region to find work. The. mining towns themselves have been decimated. Employment in YPFB has also been reduced, though not as oramatically, from 9,000 workers in 1985 to about 5,000 in 1987 .

\section{Beyond Stabilization to Economic Growth and Development}

The stabilization has eliminated much of the panic conditions that surrounded the hyperinflation in 1984 and 1985. Virtually complete price stability has been reestabilished in 80 livia during 1986 and 1987 . It is 
evident, however, that many of the deeper problems in the Bolivian economy and society that helped to cause the hyperinflation remain in place, and in some cases have deepened. We now mention some of the challenges that remain in converting the current stabilization period into the first phase of sustained economic development.

There are three sociopolitical cleavages that are serious obstacles to economic stability and long-term growth: the cleavages of incone distribution, ideology, and region.

The income distributional cleavage remains profound, and is the source of considerable political conflict. The key political problem is to moderate the nearly continuous confrontation between powerful social groups, such as organized labor and private capital, and the various regional forces. The state capitalist model attempted to finesse the income distribution problem through a combination the inflation tax, heavy foreign borrowing, or internal repression of the lower classes. None of these alternatives is effective for a long-term development strategy.

A key to a more equitable distribution of income in Bolivia is an increased tax burden on the higher income individuals. Rather than balancing the budget by eliminating the basic services of the state, such as health and education, equity and stability can only be achieved if the government makes increased efforts to secure an adequate tax base on the higher incomes. This might include a tax on land holdings, and higher taxes on luxury consumption goods. A second key to a more equitable distribution of income would be greater public spending on education in the rural sector, where most of Bolivia's poorest citizens live. Investment in the human capital of the rural peasantry is essential for long-term economic development. 
The second division to overcome is ideological, involving competing conceptions of the role of government. With the evident failures of state capitalism in the past two decades, there is a temptation on one side for a strict laissez-faire economic approach, and on the other side, for a fortified socialism. A more modulated approach is more likely to succeed. Such an approach would recognize the Government's responsibilities for infrastructure, and social investments in health and education, but also recognizes the limitations to the role of the state in the productive sector. Part of the push toward laissez-faire in Bolivia is a frank acknowledgement of the limited capacity for honest, capable public administration in the country. But this limitation could be lessened by a concerted effort to raise the standards and capacity of the state bureaucracy. A determined effort at improved training of civil servants is vital in this regard.

The third division is jectoral and regional. Mining and petroleum products can no longer be the basis of a vibrant Bolivian economy. Nor can coca production. Export diversification will require a turn to agriculture and light manufacturing, which in turn will surely entail some geographical shift in the locus of economic activity from the highlands to the lowlands. This kind of shift can be politically bruising and destructive if not handled with foresight and planning. To accomplish this restructuring the government will have to tread carefully between goals of allocating investment expenditures heavily towards the new sectors and regions, and the need to distribute the burdens and benefits of public spending in an equitable manner. 


\section{Selected List of References}

Dunkerley, James. 1984, Rebellion in the Veins, Thetford: The Thetford Press. Malloy, James. 1970. Bolivia: The Uncompleted Revolution, Pittsburgh: University of Pittsburgh Press.

Malloy, James and Eduardo Gamarra. 1987. "The Transition to Democracy in 8olivia," in James Malloy and Mitchell Seligson (eds.), Authoritarians and Democrats: Regime Transition in Latin America, Pittsburgh: University of Pittsburgh Press.

Morales, Juan Antonio. 1987. "Inflation Stabilization in Bolivia," Working Paper No. 01/87, La Paz: Universidad Catolica 8oliviana (IISEC).

Olivera, Julio. 1967. "Money, Prices and Fiscal Lags: A Note on the Dynamics of Inflation," Banca Nazionale del Lavoro Quarterly Review, Vol. 20.

Sachs, Jeffrey. 1986. "The Bolivian Hyperinflation and Stabilization," NBER Working Paper No. 2073, November.

Tanzi, Vito. 1977. "Inflation, Lags in Collection and the Real Value of Tax Revenue," IMF Staff Papers, Vol. 24. 